\title{
Ice-core evidence for widespread Arctic glacier retreat in the Last Interglacial and the early Holocene
}

\author{
Roy M. KOERNER, DAvid A. FISHER \\ Geological Survey of Canada, 601 Booth Street, Ottawa, Ontario K1A 0E8, Canada \\ E-mail:koerner@nrcan.gc.ca
}

\begin{abstract}
An early study of the various components of the Greenland, Antarctic and Canadian Arctic ice-cap cores (Koerner, 1989) suggested that during the last interglacial period, the Greenland ice sheet suffered massive retreat and Canadian ice caps melted completely. Since then, modeling has helped support this interpretation (Cuffey and Marshall, 2000). Ice-core records of stable isotopes, melt layering and chemistry from the same Canadian ice cores, and others from the Russian Arctic islands, Svalbard and Greenland are presented as evidence for a more modest, but still substantial, retreat in the early Holocene. The sections representing the first half of the Holocene in many cores have less negative $\delta^{18} \mathrm{O}$ values ( $\delta$ values) and a higher percentage of melt layers than recently deposited ice, suggesting that temperatures were $1.3-3.5^{\circ} \mathrm{C}$ warmer than today. Given that glacier balances are slightly negative today, they must have been substantially more negative during the early-Holocene thermal maximum, leading to retreat of the circumpolar ice caps. Evidence is presented to suggest that, with the exception of Academii Nauk ice cap, the ice in the Russian Arctic islands and Svalbard must have almost disappeared. In the Canadian Arctic, the larger Canadian ice caps retreated but survived. The cooling trend that followed this thermal maximum promoted re-expansion and new growth of most of the ice caps in the Russian Arctic islands and Svalbard.
\end{abstract}

\section{INTRODUGTION}

With the purpose of gaining insight into climatic change in the polar regions, ice cores have been analyzed for stable isotopes, chemistry, melt proxies and gas content to find the rate and scale of changes that have occurred over periods of up to 400000 years (e.g. Jouzel and others, 1993). Such studies reveal the relationships among the various climatic forcing elements, and, perhaps most importantly in terms of the modern anthropogenic context, the role of greenhouse gases in amplifying climatic changes (e.g. Lorius and others, 1979). Here we use many of the same ice-core records to determine when the ice caps and ice sheets began to form, when they suffered major or complete retreat, and when they recovered to readvance again. The objectives are to bring together the evidence from earlier work (Koerner, 1989, 1997) in order to put ice-sheet/ice-cap history into a longer and more continuous perspective, and also to examine the relevance and importance of the various proxies that enable such a study.

\section{THE LAST INTERGLAGIAL (SANGAMON/EEM)}

Analysis of stable isotopes, gas content and ice texture in the basal ice of several polar ice masses has been used to argue for extensive melting of the Greenland ice sheet in the last interglacial period (Koerner, 1989). In an earlier analysis, Paterson and others (1977) attributed the less negative stable-isotope $(\delta)$ values in the basal ice of a Devon Ice Cap (Canadian Arctic) core to a different source region for water vapour forming the precipitation over the drill site. Less negative values would otherwise be attributed to warmer conditions when the basal ice was formed. However, later studies of similar ice at the base of the Agassiz Ice Cap (northern Ellesmere Island, Canadian Arctic) cores found high pollen concentrations in that ice (Koerner and others, 1988). This led to the conclusion that the basal ice was formed in a warmer period than today and was in fact superimposed ice rather than ice formed by regelation at the base of the ice cap or by precipitation from a different source region. The superimposed ice was argued to have formed during the growth of a new ice cap after the area had become ice-free during the warmest parts of the prior interglacial period. This recognition inspired the examination of data available for the Camp Century (Greenland), Dye 3 (Greenland), Byrd (Antarctica) and Vostok (Antarctica) ice cores (Koerner, 1989). Comparing the texture, gas content and stable-isotope ratios among the cores and also between the basal ice and the ice above, it was concluded that Vostok was the only location where pre-Sangamon/Eem ice was present. The implication was that the retreat of the Greenland ice sheet was extensive and may have been complete. Since then, the Greenland Ice Sheet Project 2 (GISP2) (Grootes and Stuiver, 1997) and Greenland Icecore Project (GRIP) (Dansgaard and others, 1993; Souchez and others, 1994) cores have shown that the central parts of the Greenland ice sheet most likely include pre-Sangamon/Eem ice (Chappellaz and others, 1997). Together, these findings still allow for extensive retreat of the Greenland ice sheet during the Last Interglacial, a retreat that was important in terms of sea-level change.

The most recent modeling study of the history of the Greenland ice sheet (Cuffey and Marshall, 2000) agrees well with the conclusions based on the analysis of basal ice (Koerner, 1989), i.e. that there was massive retreat of the ice sheet in the last interglacial period and that the $6 \mathrm{~m}$ sea- 


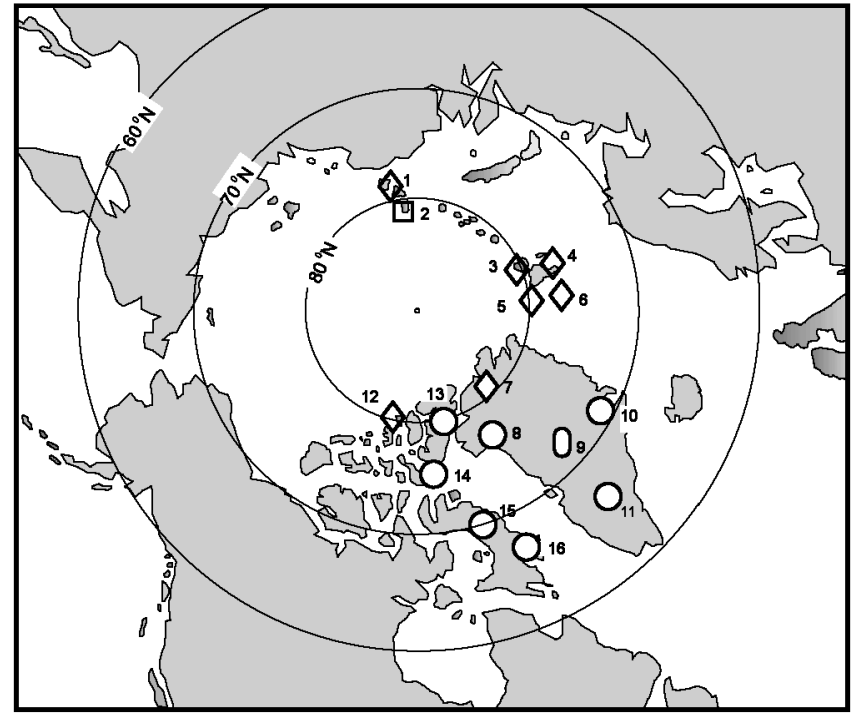

Fig. 1. Locations of ice cores discussed in the text. 1: Vavilor, 2: Academii Nauk, 3: Austfonna, 4: Gronford, 5: Hoghetta, 6: Lomonosov, 7: Hans Tausen, 8: Camp Century, 9.1, 9.2: GRIP and GISP2, 10: Renland, 11: Dye 3, 12: Meighen, 13: Agassiz, 14: Devon, 15: Barnes: 16: Penny. The symbols locate ice-core sites as follows: diamonds: ice cores that include only Holocene ice; squares: late-glacial and Holocene ice; circles: Holocene, Wisconsin/Würm and possibly Eem ice; oval: Holocene, Wisconsin/Würm, Sangamon/Eem and pre-Sangamon/Eem ice.

level rise during that time can be largely attributed to that retreat. Smaller contributions must have come from smaller ice caps and glaciers. This of course leads to the conclusion that West Antarctica did not play an important role in the process of sea-level change.

Figure 1 shows the locations, and Figure 2 the records, from three ice caps in Canada, four in Greenland (where the GISP2 core may be considered together with the GRIP summit core) and one from Antarctica. We restrict our analysis to broad comparisons among the cores because the pre-Holocene ice in the Canadian cores occurs over $<12 \mathrm{~m}$, so that the resolution is limited. Despite the quite different thicknesses of the ice masses (128-3029 m), basic stratigraphic sections are comparable among the cores. These are designated as Holocene (A), Wisconsin/ Würm (B) and early Wisconsin/Würm and/or Sangamon/Eem (C). Pre-Sangamon/ Eem ice (D) is unequivocally apparent in the Vostok ice core. Its presence in the GRIP and GISP2 ice cores is slightly equivocal, but it is most likely present mixed with ice of Eemian age (Chappellaz and others, 1997). Assuming no basal melt (Cuffey and Marshall, 2000), the absence of preSangamon/Eem ice in all but the central Greenland ice cores demonstrates that there was substantial retreat of the Greenland ice during the last interglacial period. The Canadian ice cores, which show no evidence for pre-Sangamon/Eem ice, are from sites close to or at the top of the flowline, strongly suggesting complete disappearance of those ice caps.

The ice caps and ice sheet we discuss here may be described as products of a continental- rather than marinetype climate. This means they are dominated, particularly during the growth and decay stages, by summer (melt) conditions rather than winter (accumulation) conditions. We make this classification based on 40 years of mass-balance monitoring of the glaciers in the Queen Elizabeth Islands of the Canadian eastern Arctic islands (Koerner and Lundgaard,

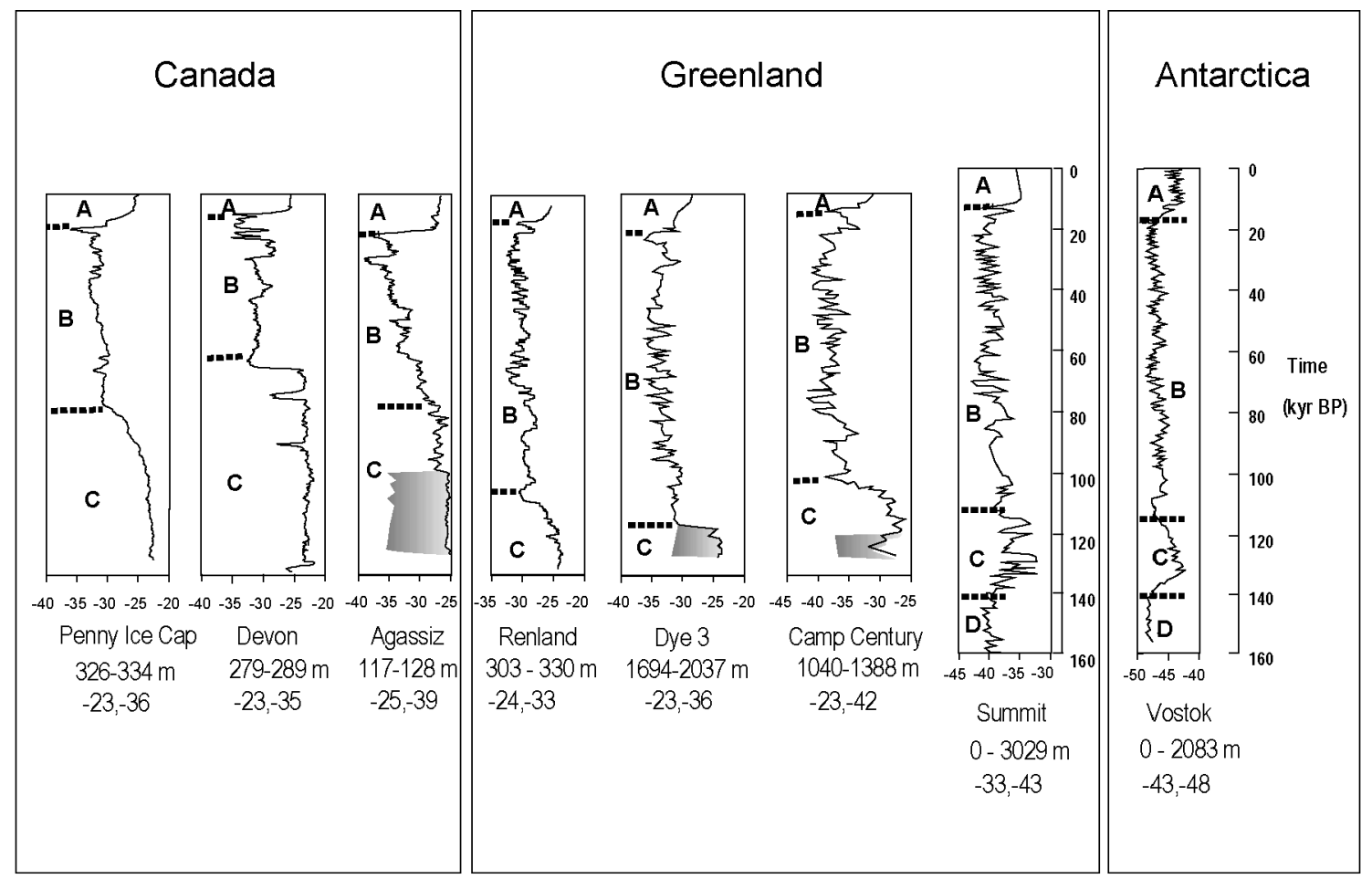

Fig. 2. For locations of cores see Figure 1. A: Holocene; B:Wisconsin/Würm; C: early Wisconsin/Würm or Sangamon/Eem; D: preSangamon/Eem. The Summit (Dansgaard and others, 1993) and Vostok cores (Jouzel and others, 1993; Petit and others, 1999) are plotted on time-scales. However, for ice older than $110 \mathrm{kyr}$ the Summit time-scale is inaccurate due to dynamic disturbance of the ice at those depths. The Penny (Fisher and others, 1998), Agassiz (Fisher and others, 1995), Devon (Paterson and others, 1977) and Renland (Hansson, 1994) cores are plotted on linear depth scales, the intervals for which are indicated below each profile. The negative values shown in the lowermost text below each profile are, respectively, the oxygen isotope values near the base, and the most negative values in the Wisconsin/Würm ice. The shaded sections in some of the cores designate silty sections of the cores. 


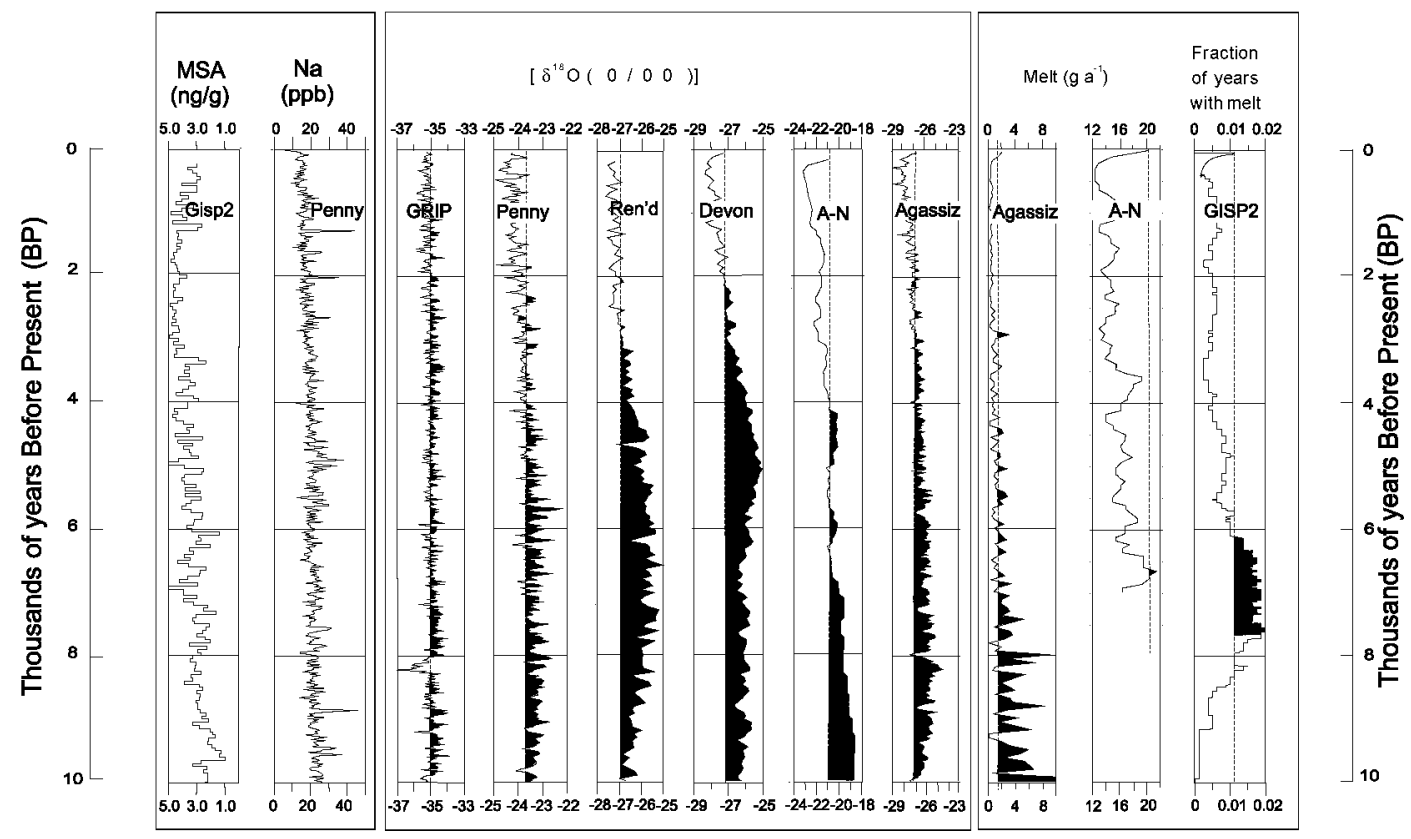

Fig. 3. Holocene sections of cores from GISP2 (MSA) (NSIDC, 1997); Penny ( Na) (Fisher and others, 1998); Summit-GRIP $(\delta)$ (Fohnsen and others, 1997); Penny ( $\delta$ ) (Fisher and others, 1998); Renland ( $\delta$ ) (Hansson, 1994); Devon ( $\delta$ ) (Paterson and others, 1977); Academii Nauk $(\delta)$ (Koerner, 1997); Agassiz ( $\delta$ ) (Fisher and others, 1995); Agassiz (melt) (Koerner and Fisher, 1990); Academii Nauk (melt) (Koerner, 1997); GISP2 (1000 year running mean of melt frequency (number of melt features per 100 years) ) (Alley and Anandakrishnan, 1995). Shaded parts of the $\delta$ and melt records denote periods with values above the present-day (approximately last 100 years) values (the early-Holocene GRIP melt-frequency values are not shaded as they are less reliable ( see text)). References for the Academii Nauk data can be found in Koerner (1997).

1995), which show that summer conditions dominate the mass balance whereas winter snow accumulation bears very little relationship to that balance. In this case, ice-cap/ice-sheet attrition is driven by warmer summers, while growth is driven by cooler summers. After the complete disappearance of ice caps and the retreat of the Greenland ice, summer cooling would promote regrowth not simply by marginal advance but also by lowering the equilibrium line to ice-free terrain beyond the ice margins (Koerner, 1997). Ice formed in this manner develops from the survival of snowfields through the summer period and is, in effect, superimposed ice. We believe this is the kind of ice found at the base of the Canadian, Renland, Camp Century and Dye 3 ice cores. Its presence and the absence of pre-Sangamon/Eem ice at the Camp Century and Dye 3 sites, suggests that those sites were ice-free during the Last Interglacial and that following the Interglacial, new ice masses grew in those locations. That ice later joined with the central part of the Greenland ice sheet, which does contain deep pre-Sangamon/Eem ice.

The stable-isotope $(\delta)$ values are similar in the ice that lies just above the bedrock in all of the cores except the Summit and Vostok cores. They all fall within the range $-23 \%$ to $-25 \%$ (Fig. 2), indicating that ice growth at each site occurred under similar climatic conditions, slightly warmer than today. However, timing of regrowth at each of those sites would have occurred at different stages of the transition from interglacial to glacial climate. In part, warmer conditions can be attributed to lower site elevations, as growth would have begun on bedrock. The $\delta$ values in the interglacial $(\mathrm{C})$ section of the Summit core reach much more negative values than in the growth stages of the other Greenland cores. This would be expected when comparing the stable-isotope signatures of a low-elevation, growthstage part of the ice sheet with those of a higher-elevation, established part of the same ice sheet. The distribution of cores with and without growth-stage and Sangamon/Eem ice (Fig. 1) indicates that the Sangamon/Eem Interglacial saw the demise in the circumpolar region of all but the central parts of the Greenland ice sheet.

\section{THE HOLOGENE PERIOD}

The locations of ice caps that include a complete Holocene record are shown in Figure 1. The $\delta$ records for all the cores, the melt record for three, the Na record for Penny Ice Cap and a methanesulphonate (MSA) record for GISP2 (NSIDC, 1997) are shown in Figure 3. Sources for the Russian data can be found in Koerner (1997). Zagorodnov (1998) comments on the time-scales used for these cores. We have used the glacial/interglacial "step" and the presence of very negative $\delta$ (Wisconsin/ Würm) ice below that as evidence that these records (except that for Academii Nauk melt) do cover the entire Holocene period.

The only melt record that extends back over the entire 10000 year period is from Agassiz Ice Cap (Fig. 3). It shows a very early thermal maximum in the Holocene. This is somewhat different from most of the $\delta$ records (Fig. 3), including that from the same ice core, which show a thermal maximum occurring later in the Holocene, in some cases as late as mid-Holocene. The reason for the melt $/ \delta$ difference in the timing of this maximum is a topic of present research. However, borehole paleothermometry reconstructions push the thermal maximum in central Greenland earlier than that derived solely from $\delta$ records (e.g. personal communication from G. D. Clow, 2001). Antarctic records from Vostok (Jouzel and others, 1993), Dome Fuji (Watanabe and others, 1999) and Taylor Dome (Steig and others, 2000) also show a 


\section{$\delta^{18} \mathrm{O}(0 / 00)$}

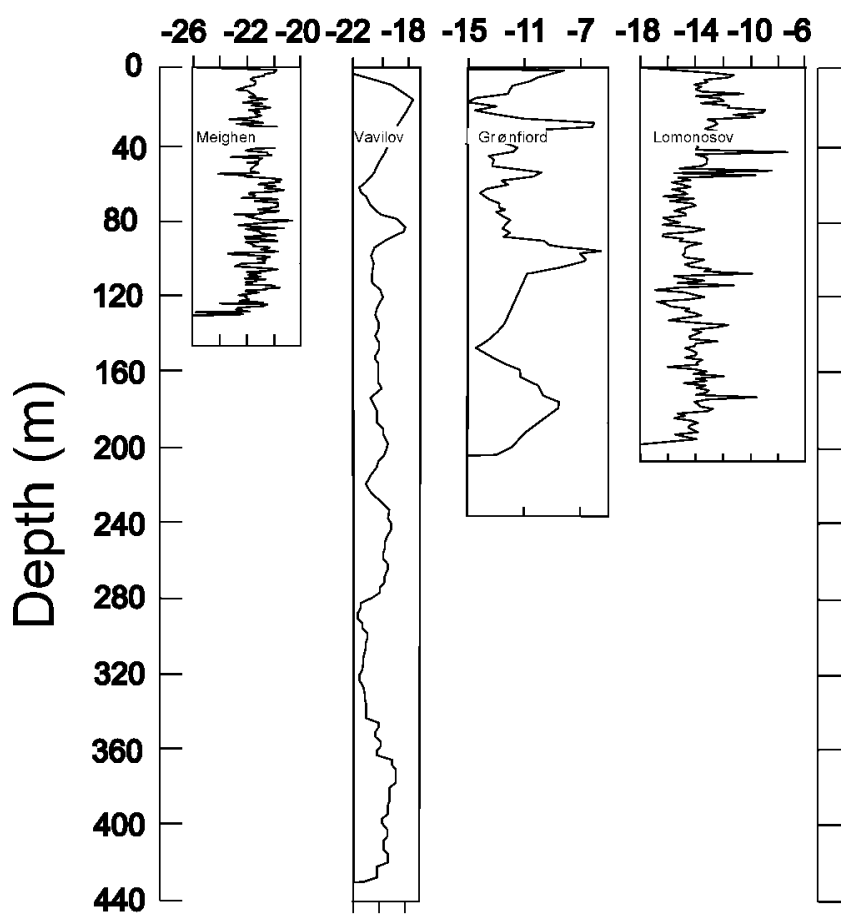

Fig. 4. $\delta$ values for two cores from Svalbard (Lomonosov, Gronfiord), for Vavilov ice cap, Russian Arctic Islands, and for Meighen Ice Cap, eastern Canadian Arctic. References for the core data can be found in Koerner (1997).

very early Holocene thermal maximum. Furthermore, studies of pollen in Arctic Canada (Ritchie and others, 1983), lichens and lake sediments in Svalbard (Werner, 1988; Svendsen and Mangerud, 1997) and bowhead whales and driftwood in the Canadian Arctic islands (Dyke and Morris, 1990; Dyke and others, 1996) have drawn similar conclusions about the early timing of the thermal maximum in the Holocene.

The melt records (Fig. 3) show a persistent cooling trend of about $2.0-2.5^{\circ} \mathrm{C}$ throughout the Holocene until about 150 years ago, followed by a $0.5^{\circ} \mathrm{C}$ warming (Koerner and Fisher, 1990). The $\delta$ records displace the start of the cooling trend closer to the mid-Holocene, but a common cooling trend is evident in all these records for the last 5000 years, including the GRIP core record when corrected for elevation effects (Johnsen and others, 1995). Assuming a transfer function of $0.62 \%$ per $1{ }^{\circ} \mathrm{C}$ (Dansgaard and others, 1973), the cooling derived from the $\delta$ profiles (except for GRIP) is $1.3-3.5^{\circ} \mathrm{C}$. Using the appropriate calibration of isotopes for the GRIP and GISP2 cores (Alley and others, 1997), there is also a cooling of about $2.0^{\circ} \mathrm{C}$ in central Greenland over the same period.

It can be argued that isostatic recovery of the bed under the ice caps during the Holocene compromises the temperature record. It would do so if the elevation of the ice-cap surface gradually increased during the Holocene and thereby effected a non-climatic cooling trend very much like the one we see. Koerner and Fisher (1990) discussed this with respect to the Canadian Arctic islands. They referred to earlier work (Koerner, 1979) which showed there is presently no relationship between $\delta$ and elevation in that area. However, the climatic cooling during the Holocene derived from the $\delta$ record $\left(2.5^{\circ} \mathrm{C}\right)$ is very similar to that derived from the melt record $\left(2.0^{\circ} \mathrm{C}\right)$ which should be affected by elevation changes. They therefore believed that both the $\delta$ and melt records were good measures of climatic change. Yet there are differences in the trends between the Agassiz $\delta$ and melt records. These differences might be explained by the effect of elevation changes on the melt record but not necessarily that of isostatic rebound. Isostatic rebound must be more than balanced by thinning of the ice causing that uplift. Reeh's (1984) model of the Wisconsin/Würm ice cover in the Canadian Arctic Islands shows that the ice was of local origin. If correct, this would discount the effect of much thicker ice elsewhere. At the drill sites, the same model shows elevations 200-250 m higher than today. Thus any elevationchange effect would be to reduce the trends we see in the melt profile for Agassiz Ice Cap. This is because thinning of the ice cap at the drill site would more than outweigh isostatic uplift which, over the Holocene period, is approximately $120 \mathrm{~m}$ at present sea level (Blake, 1993). Similar arguments may apply to the Academii Nauk profiles also.

We also show the sea-salt record (as represented by $\mathrm{Na}$ concentrations) from a Penny Ice Cap core (Fig. 3). Grumet and others (1997) showed that the sea-salt record from that core was related to sea-ice extent in nearby Baffin Bay, whereby higher concentrations were associated with more open water. The 10000 year record (Fisher and others, 1998) suggests decreasing sea-ice extent during the Holocene. There is also evidence (Legrand and others, 1997) of a positive relationship between MSA (plotted inversely in Fig. 3) and sea ice. The Holocene record from GISP2 shows low concentrations of MSA (i.e. low concentrations of sea ice) in central Greenland in the early Holocene, increasing to high concentrations approximately $2 \mathrm{kyr} \mathbf{B P}$.

In summary, it may be said that while there are obvious disagreements among some of the records, the overall trend appears to be for an extended period of conditions warmer than present throughout the early Holocene, followed by a cooling trend, common to all the records, in the second half of the Holocene.

We also examine ice-core records from smaller ice caps than those discussed so far to examine whether they have existed throughout the Holocene. Two are from Svalbard (Lomonosov and Grønfiord), one from the Russian Arctic islands (Vavilov) and one from the Canadian Arctic Islands (Meighen Ice Cap) (Fig. 4). These records, firstly, have no climate-stratigraphic units and thus show no evidence for Wisconsin/Würm ice, and, secondly, do not show the cooling trend seen at the other locations. We infer that these cores are from ice caps that began to regrow in the second half of the Holocene. Two other cores, not shown here, from Hans Tausen Iskappe, North Greenland (Hammer and others, in press), and the Høghetta ice dome, Svalbard (Fujii and others, 1990), also appear to belong to the Holocene. Organic material from near the base of the Høghetta ice dome has been dated to about 5000 years BP. Madsen and Thorsteinsson (2001), from a study of the textures, fabrics and melt-layer stratigraphy, placed the growth of Hans Tausen Iskappe into the last 3500-4500years.

\section{DISGUSSION}

We focus the discussion of the ice-core records on the Holocene, in order to put modern climate into perspective. To do this, the modern (last 100 years) melt and $\delta$ values are extrapolated back along the entire 10000 years of record 

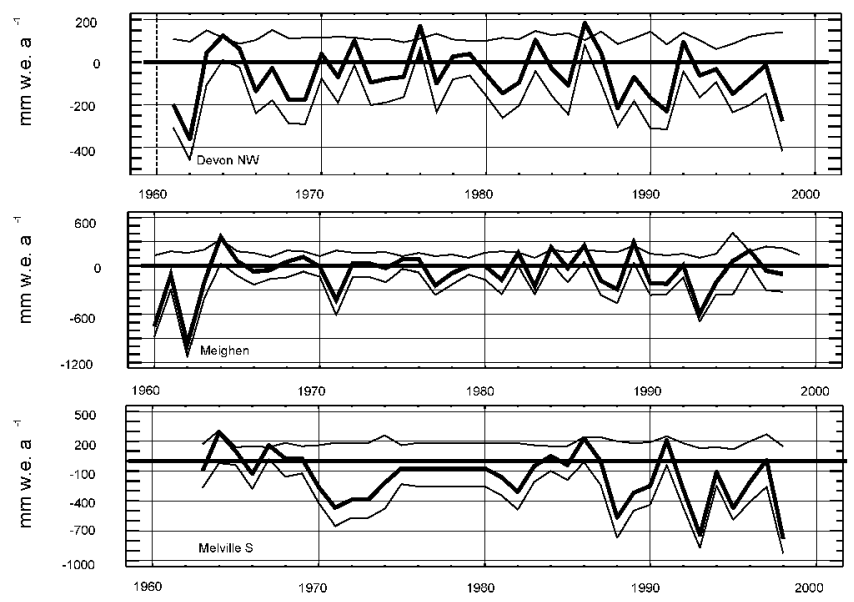

Fig. 5. Mass balance for three eastern Canadian Arctic ice caps. The upper line represents annual snow accumulation (winter balance), the lower line the summer balance (mainly snow/ice melt), and the middle line the net balance (sum of the two where summer balance is usually negative and winter balance positive). Data on file at Geological Survey of Canada (R. M. Koerner).

(Fig. 3). In general, the modern temperatures (except for the Academii Nauk melt record) are much lower than temperatures in most of the first half of the Holocene. We also present over three decades of mass-balance measurements from the eastern Canadian Arctic (Fig. 5). Two of these records, from Meighen and Devon northwest, are from ice caps where icecore records, discussed above, were taken. In all cases the balances are slightly negative. This is also true of other circumpolar glaciers, including those on Svalbard, where massbalance measurements have been made (Dowdeswell and others, 1997). It follows that the first few thousand years of the Holocene must have been a time of rapid glacier retreat, not only of the Laurentide and Fennoscandian ice sheets, but also of all the circumpolar ice caps and icefields, and also the Greenland ice sheet. Regional ice-mass retreat would explain the absence of Wisconsin/Würm ice on the ice caps whose records are shown in Figure 4; the icefields either melted away completely or were diminished to the extent that the drill-site locations were free of ice.

Following the period of retreat in the first half of the Holocene, temperatures cooled through most of its second half (Fig. 3). Consequently, ice masses began to grow again. Maximum dimensions were probably reached about 200 years ago (Fig. 3). Because of a lack of Wisconsin/Würm ice outcropping at the margins of ice caps studied in the Canadian eastern Arctic, we think that regrowth must have been rapid, at least in that region. Reeh and others, (1991, 2002) "mined" ice at various locations around the edge of the Greenland ice sheet and found a quasi-continuous record of Holocene and pre-Holocene ice outcropping there. Zdanowicz and others (2002) have found the same is true on the margins of Barnes Ice Cap (Fig. 1). This is not the case in the other Canadian ice caps. Sampling ice from Devon Ice Cap, specifically its northwest margin and an outlet glacier, Koerner and Russell (1979) found only one sample out of thirteen on the margin had a $\delta$ value $(-30.5)$ similar to that of Wisconsin/Würm ice. All of the ice on the outlet glacier, including the ice cliff at the end, had $\delta$ values characteristic of Holocene ice. Similar sampling at higher resolution along the same profiles on Devon Ice Cap but also at the margins of
Agassiz Ice Cap by N. Reeh (personal communication, 1987) did not find any ice with $\delta$ values sufficiently negative to assign a Wisconsin/Würm origin to that ice. The combined results suggest that Wisconsin/Würm ice, which in a steadystate ice cap would emerge at the margins, is buried beneath younger ice there. Such a pattern would occur if readvance in the second half of the Holocene were chiefly due to lowering of the long-period equilibrium line below and beyond the icecap margins. This was not the case in Greenland or on Barnes Ice Cap, where pre-Holocene ice does outcrop at the margins. It is most likely that, as a remnant of the Laurentide ice sheet (Zdanowicz and others, 2002), Barnes Ice Cap has been in continuous retreat throughout the Holocene. In Greenland, cooling in the second half of the Holocene has lowered the equilibrium line, but not beyond the margins of the ice sheet.

\section{GONGLUSIONS}

Low-resolution interpretations of ice cores from various locations in the Arctic indicate that only a greatly diminished Greenland ice sheet survived through the last interglacial period. The lack of pre-interglacial ice in cores from circumpolar ice caps and icefields indicates they may have decayed completely. While retreat has been much more restricted during the present interglacial period, the thermal maximum that occurred in the first half of that period produced a very negative mass balance on all ice masses, causing the disappearance of smaller ice caps and icefields in the circumpolar regions. A positive mass balance then regenerated growth to reach maximum volume about 100-200years ago. Since then, with the onset of global warming about 150 years ago, the ice caps have begun to retreat again. If the predictions of general circulation models prove true, this retreat will continue until the effects of anthropogenic forcing disappear and the natural cooling cycle, driven by orbital parameters, is re-established.

\section{AGKNOWLEDGEMENTS}

We wish to acknowledge valuable comments from S.J. Marshall and an anonymous referee on an early draft of the paper.

\section{REFERENCES}

Alley, R. B. and S. Anandakrishnan. 1995. Variations in melt-layer frequency in the GISP2 ice core: implications for Holocene summer temperatures in central Greenland. Ann. Glaciol., 21, 64-70.

Alley, R. B., A. M. Agústsdóttir and P.J. Fawcett. 1999. Ice-core evidence for late-Holocene reduction in North Atlantic Ocean heat transport. In Clark, P. U., R. S. Webb and L. D. Keigwin, eds. Mechanisms of global climate change at millennial time scales. Washington, DC, American Geophysical Union, 301-312. (Geophysical Monograph 112.)

Blake, W., Jr. 1993. Holocene emergence along the Ellesmere Island coasts of northernmost Baffin Bay. Nor. Geol. Tidsskr., 73(3), 147-160.

Chappellaz, J., E. Brook, T. Blunier and B. Malaizé. 1997. $\mathrm{CH}_{4}$ and $\delta^{18} \mathrm{O}$ of $\mathrm{O}_{2}$ records from Antarctic and Greenland ice: a clue for stratigraphic disturbance in the bottom of the Greenland Ice Core Project and the Greenland Ice Sheet Project 2 ice cores. 7. Geophys. Res., 102(C12), $26,547-26,557$.

Cuffey, K. M. and S.J. Marshall. 2000. Substantial contribution to sea-level rise during the last interglacial from the Greenland ice sheet. Nature, 404(6778), 591-593.

Dansgaard, W., S. J. Johnsen, H. B. Clausen and N. Gundestrup. 1973. Stable isotope glaciology. Medd. Grønl., 197(2), 1-53.

Dansgaard, W. and 10 others. 1993. Evidence for general instability of past climate from a 250-kyr ice-core record. Nature, 364(6434), 218-220.

Dowdeswell, J. A. and 10 others. 1997. The mass balance of circum-Arctic 
glaciers and recent climate change. Quat. Res., 47(1), 1-14.

Dyke, A. S. and T. F. Morris. 1990. Postglacial history of the bowhead whale and driftwood penetration: implications for paleoclimate in the central Canadian Arctic. Geol. Surv. Can. Pap. 89-24.

Dyke, A. S., J. Hooper and J. M. Savelle. 1996. A history of sea ice in the Canadian Arctic Archipelago based on postglacial remains of the Bowhead Whale (Balena mysticetus). Arctic, 49(3), 235-255.

Fisher, D. A., R. M. Koerner and N. Reeh. 1995. Holocene climatic records from Agassiz Ice Cap, Ellesmere Island, N.W.T., Canada. Holocene, 5(1), 19-24.

Fisher, D. A. and 12 others. 1998. Penny Ice Cap cores, Baffin Island, Canada, and the Wisconsinan Foxe Dome connection: two states of Hudson Bay ice cover. Science, 279(5351), 692-695.

Fujii, Y. and 10 others. 1990.6000 -year climate records in an ice core from the Høghetta ice dome in northern Spitsbergen. Ann. Glaciol., 14, 85-89.

Grootes, P. M. and M. Stuiver. 1997. ${ }^{18} \mathrm{O} /{ }^{16} \mathrm{O}$ variability in Greenland snow and ice with $10^{-3}$ to $10^{5}$ year time resolution. 7. Geophys. Res., 102(C12), $26,455-26,470$

Hammer, C. U., S. J. Johnsen, H. B. Clausen, D. Dahl-Jensen, N. Gundestrup and J. P. Steffensen. 2001. The paleoclimate record from a $345 \mathrm{~m}$ long ice core from the Hans Tausen Iskappe. Medd. Gronl., Geoscience 39, 87-95.

Hansson, M. E. 1994.The Renland ice core: a Northern Hemisphere record of aerosol composition over 120000 years. Tellus, 46B(5), 390-418.

Johnsen, S. J., D. Dahl-Jensen, W. Dansgaard and N. S. Gundestrup. 1995. Greenland paleotemperatures derived from GRIP borehole temperature and ice core isotope profiles. Tellus, 47B (5), 624-629.

Johnsen, S. J. and 14 others. 1997. The $\delta^{18} \mathrm{O}$ record along the Greenland Ice Core Project deep ice core and the problem of possible Eemian climatic instability. F. Geophys. Res., 102(C12), 26,397-26,410.

Jouzel, J. and 16 others. 1993. Extending the Vostok ice-core record of palaeoclimate to the penultimate glacial period. Nature, 364(6436), 407-411.

Koerner, R. M. 1979. Accumulation, ablation, and oxygen isotope variations on the Queen Elizabeth Islands ice caps, Canada. 7. Glaciol., 22(86), 25-41.

Koerner, R. M. 1989. Ice core evidence for extensive melting of the Greenland ice sheet during the last interglacial. Science, 244(4907), 964-968.

Koerner, R. M. 1997. Some comments on climatic reconstructions from ice cores drilled in areas of high melt. f. Glaciol., 43(143), 90-97. (Erratum: 43(144), p. 375-376,

Koerner, R. M. and D. A. Fisher. 1990. A record of Holocene summer climate from a Canadian high-Arctic ice core. Nature, 343(6259), 630-631.

Koerner, R. M. and L. Lundgaard. 1995. Glaciers and global warming. Géogr. Phys. Quat., 49(3), 429-434.

Koerner, R. M. and R. D. Russell. 1979. $\delta^{18} \mathrm{O}$ variations in snow on the Devon Island ice cap, Northwest Territories, Canada. Can. 7. Earth Sci., 16(7), 1419-1427.

Koerner, R. M., J. C. Bourgeois and D. A. Fisher. 1988. Pollen analysis and discussion of time-scales in Canadian ice cores. Ann. Glaciol., 10, 85-91.

Legrand, M. and 6 others. 1997. Sulfur-containing species (methanesulfonate and $\mathrm{SO}_{4}$ ) over the last climatic cycle in the Greenland Ice Core Project (central Greenland) ice core. 7. Geophys. Res., 102(C12), 26,663-26,679

Lorius, G., L. Merlivat, J. Jouzel and M. Pourchet. 1979. A 30,000-yr isotope climatic record from Antarctic ice. Nature, 280(5724), 644-648.

Madsen, K. N. and Th. Thorsteinsson. 2001. Textures, fabrics, and melt layer stratigraphy in the Hans Tausen ice core, North Greenland: indications of late Holocene ice cap generation? Medd. Gronl., Geoscience 39, 97-114.

National Snow and Ice Data Center (NSIDC). 1997. The Greenland Summit ice cores. Boulder, CO, University of Colorado. Cooperative Institute for Research in Environmental Sciences. National Snow and Ice Data Center, Distributed Active Archive Center.

Paterson, W. S. B. and 7 others. 1977. An oxygen-isotope climatic record from the Devon Island ice cap, Arctic Canada. Nature, 266(5602), 508-511.

Petit, J.-R. and 18 others. 1999. Climate and atmospheric history of the past 420,000 years from the Vostok ice core, Antarctica. Nature, 399(6735), 429-436.

Reeh, N. 1984. Reconstruction of the glacial ice covers of Greenland and the Canadian Arctic islands by three-dimensional, perfectly plastic icesheet modelling. Ann. Glaciol., 5, 115-121.

Reeh, N., H. Oerter, A. Letréguilly, H. Miller and H.-W. Huberten. 1991. A new, detailed ice-age oxygen-18 record from the ice-sheet margin in central West Greenland. Palaeogeogr., Palaeoclimatol., Palaeoecol., Global Planet. Change Sect., 90(4), 373-383.

Reeh, N., H. Oerter and H. H. Thomsen. 2002. Comparison between Greenland ice-margin and ice-core oxygen-18 records. Ann. Glaciol., 35 (see paper in this volume).

Ritchie, J. C., L. C. Cwynar and R.W. Spear. 1983. Evidence from northwest Canada for an early Holocene Milankovitch thermal maximum. Nature, 305(5930), 126-128.

Souchez, R. and 8 others. 1994. Stable isotopes in the basal silty ice preserved in the Greenland ice sheet at Summit: environmental implications. Geophys. Res. Lett., 21 (8), 693-696.

Steig, E. J. and 7 others. 2000. Wisconsinan and Holocene climate history from an ice core at Taylor Dome, western Ross Embayment, Antarctica. Geogr. Ann., 82A(2-3), 213-235.

Svendsen, J. I. and J. Mangerud. 1997. Holocene glacial and climatic variations on Spitsbergen. Holocene, 7 (1), 45-57.

Watanabe, O. and 16 others. 1999. Basic analyses of Dome Fuji deep ice core. Part 1: stable oxygen and hydrogen isotope ratios, major chemical compositions and dust concentration. Polar Meteorol. Glaciol., 13, 83-89.

Werner, A. 1988. Holocene glaciation and climate change, Spitsbergen. (Ph.D. thesis, University of Colorado, Boulder, CO.)

Zagorodnov, V. S. 1998. Correspondence. Comments on "Some comments on climatic reconstructions from ice cores drilled in areas of high melt" by Roy M. Koerner. 7. Glaciol., 44(146), 191-193.

Zdanowicz, C., D. A. Fisher, I. Clark and D. Lacelle. 2002. An ice-marginal $\delta^{18} \mathrm{O}$ record from Barnes Ice Cap, Baffin Island, Canada. Ann. Glaciol., 35 (see paper in this volume). 